\title{
Two new species of the genus Acerocnema Becker, 1894 (Diptera: Scathophagidae) from Far East of Russia
}

\author{
Ава новых вида рода Acerocnema Becker, 1894 \\ (Diptera: Scathophagidae) с Аальнего Востока России
}

\author{
A.L. Ozerov ${ }^{1}$, M.G. Krivosheina ${ }^{2}$ \\ А. $\Lambda$. Озеров ${ }^{1}$, М.Г. Кривошеина ${ }^{2}$

\begin{abstract}
${ }^{1}$ Zoological Museum, Moscow Lomonosov State University, Bol'shaya Nikitskaya 2, Moscow 125009, Russia. E-mail: ozerov2455 (a)rambler.ru

1 Зоологический музей, Московский государственный университет им. М.В. Ломоносова, Большая Никитская ул., 2, Москва 125009, Россия.

${ }^{2}$ A.N. Severtsov Institute of Ecology and Evolution, Russian Academy of Sciences, Leninsky prospect, 33, Moscow 119071, Russia.

E-mail: dipteramarina@rambler.ru
\end{abstract} \\ ${ }^{2}$ Институт проблем экологии и эволюции им. А.Н.Северцова РАН, Ленинский проспект, 33, Москва 119071, Россия.
}

KEY WORDS: Diptera, Scathophagidae, Acerocnema, new species, key, Russia.

КЛЮЧЕВЫЕ СЛОВА: Diptera, Scathophagidae, Acerocnema, новый вид, определительная таблица, Россия.

ABSTRACT. Acerocnema gorodkovi sp.n. and Acerocnema nitens sp.n., from the family Scathophagidae (Diptera), are described from Khabarosk Krai and Primorskiy Krai, Russia. Key for determination of species from Russia is given.

РЕЗЮМЕ. Описаны два новых для науки вида, Acerocnema gorodkovi sp.n. и Acerocnema nitens sp.n., из семейства Scathophagidae (Diptera), с территории Хабаровского и Приморского краев, Россия. Дан ключ для определения видов рода Acerocnema фауны России.

\section{Introduction}

Acerocnema Becker, 1894 is one of the small genera within the family Scathophagidae, which until the present time has comprised 11-12 species distributed in the Holarctic Region [Gorodokov, 1986; Vockeroth 1987; Iwasa, 2014]. 7 species are registered in Russia [Stackelberg, 1952; Ozerov, 2006, 2013, 2014, 2015].

The genus Acerocnema is characterised by the combination of next characters: arista bare or short pubescent; palpus slender or distinctly spatulate, without strong apical/subapical seta; proepisternum covered with hairs at middle or in anterior part; fore femur ventrally without short black spines; anepisternum covered with setulae usually along dorsal margin and in posterior part only, without setulae posterior to anterior spiracle; katepisternum with one strong seta in posterodorsal corner; anepimeron bare; postmetacoxal bridge absent; scutellum with two pairs of setae, basal and apical; male sternite 5 usually long and bilobate posteriorly, directed downwardly and perpendicularly to other sternites (Fig. 6).

The specimens examined for this study are deposited in the Zoological Museum, Moscow State University, Russia (ZMUM) and Zoological Institute of Russian Academy of Sciences, St. Petersburg, Russia (ZISP). Terminology follows McAlpine [1981] and Cumming et al. [2009], except that "postpedicel" is used for antennal flagellomere 1 (third antennal segment) [Stuckenberg, 1999].

\section{Descriptions of a new species}

Acerocnema gorodkovi, sp.n.

Figs. 1, 3-5.

MATERIAL. Holotype $\sigma^{7}$, RUSSIA: Khabarosk Krai, Malyshevo $\left(48.7317^{\circ} \mathrm{N} 135.6131^{\circ} 7 \mathrm{E}\right)$ near Petropavlovka, 13.V.1973, Gorodkov (ZISP).

DESCRIPTION. Male. Length of body $3.6 \mathrm{~mm}$. Length of wing $3.4 \mathrm{~mm}$.

Head in profile higher than wide. Frontal vitta matt, black, but yellow in apical quarter; fronto-orbital plate black, subshining. Face, parafacial and gena yellow. Ocellar triangle black, shining. Postcranium black in upper part and yellowish in lower third, delicately greyish dusted. Height of gena about 4 times less than vertical diameter of eye. Setae: 3 orbitals, 4 frontals,

How to cite this article: Ozerov A.L., Krivosheina M.G. 2018. Two new species of the genus Acerocnema Becker, 1894 (Diptera: Scathophagidae) from Far East of Russia // Russian Entomol. J. Vol.27. No.2. P.210-214. doi: $10.15298 /$ rusentj.27.2.13 

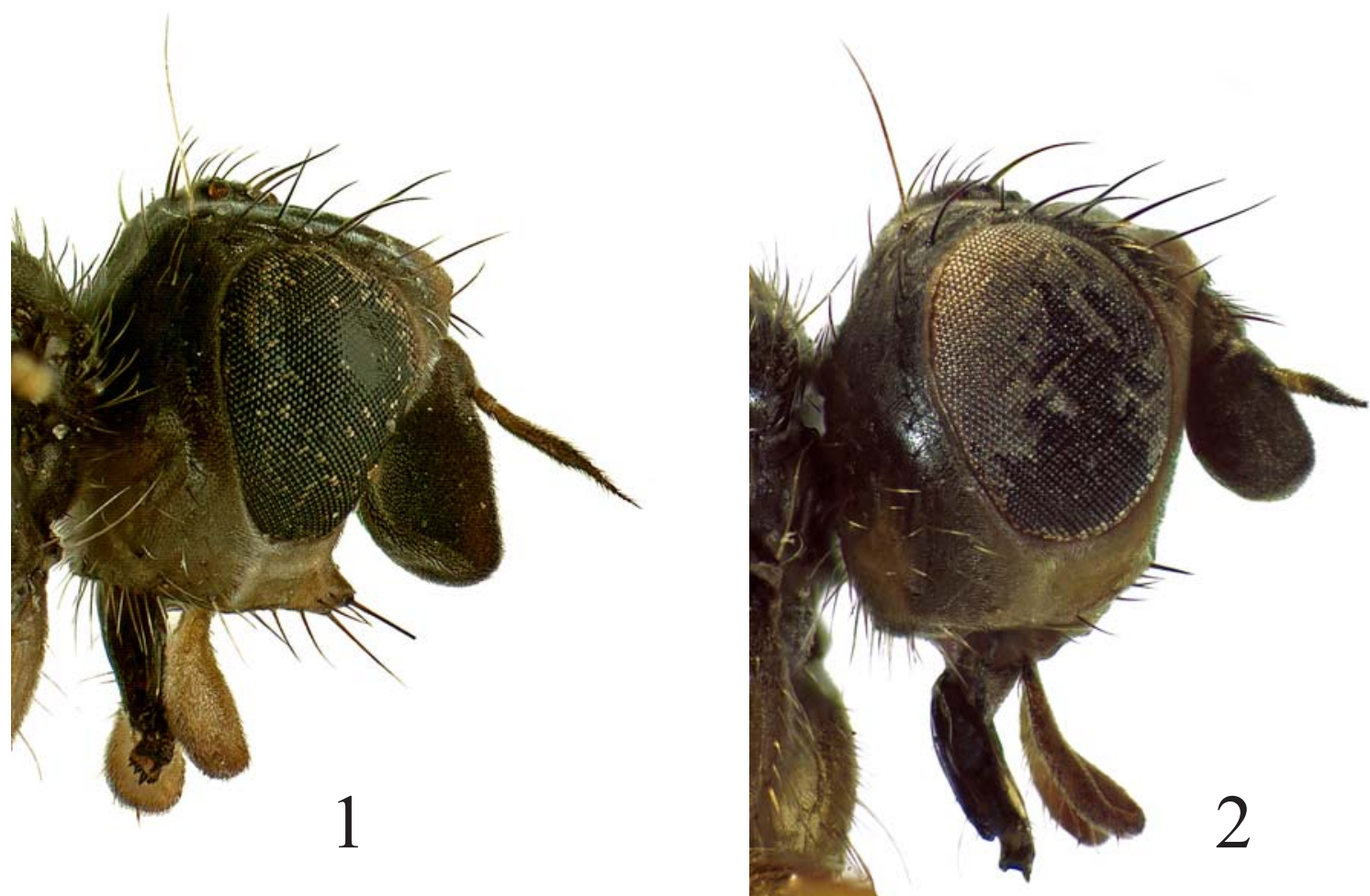

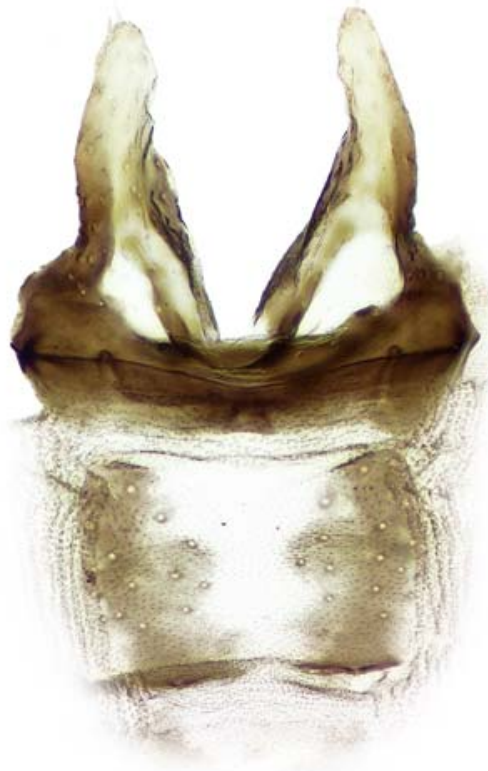

3

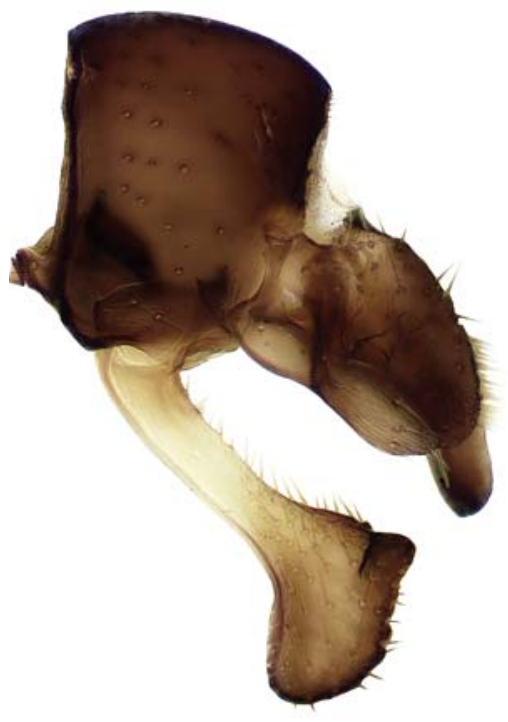

4

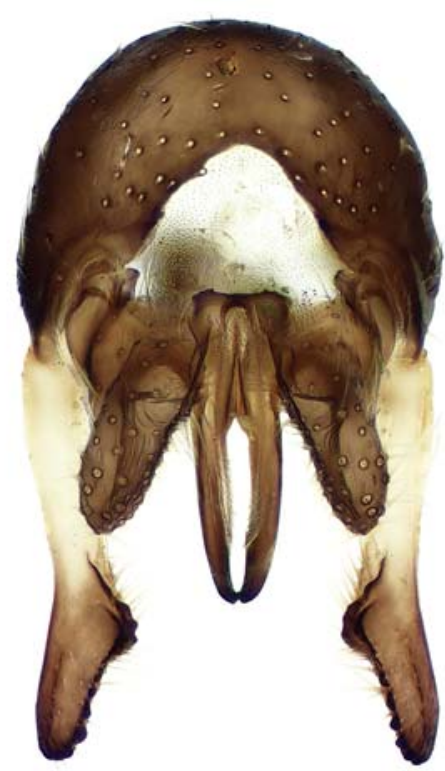

5

Figs. 1-5. Acerocnema gorodkovi, sp.n., holotype $\sigma^{7}(1,3-5)$ and Acerocnema breviseta (Zetterstedt, 1846), $\sigma^{7}$ (2): 1, 2 — head; 3 — sternites 4 (lower) and 5 (upper); 4 - epandrium, cerci and surstyli, lateral view; 5 - same, dorsal view.

Рис. 1-5. Acerocnema gorodkovi, sp.n., голотип (1, 3-5) и Acerocnema breviseta (Zetterstedt, 1846) (2): 1, 2 - голова; 3 стерниты 4 (внизу) и 5 (вверху); 4 - эпандрий, церки и сурстили, сбоку; 5 - то же, сверху. 
1 ocellar, 1 postocellar (small, parallel), 1 inner vertical, 1 outer vertical; 2 strong vibrissae on well developed vibrissal angle (Fig. 1) present. Scapus, pedicel and postpedicel black. Postpedicel wide, approximately 1.5 times as long as wide. Arista black, widened throughout its length, very short pubescent. Palpus clavate, yellow.

Thorax black, delicately whitish dusted; scutum with four shining stripes: two short at middle, and two distally from dorsocentral lines. Acrostichals as hairs, in twofour rows, prescutellar pair not differentiated from other hairs on scutum, dorsocentrals $2+3$, intra-alars $0+1$, supra-alars $1+2$, postpronotals 2 , notopleurals 2 , postalars 2. Proepisternum with hairs in central part, with long seta near lower margin. Proepimeron with long seta. Anepisternum covered with hairs in posterior half and with 2-3 long setae along posterior margin. Katepisternum with hairs in ventral corner and 1 strong seta in posterodorsal corner. Anepimeron bare. Scutellum black, shining, with a pair of basal scutellar and a pair of apical scutellar setae. All thoracic setae and hairs yellow.

Legs yellow. Mid tibia with 1 anterodorsal seta. Hind tibia with 2 anterodorsal setae, also with 1 preapical anterodorsal and 1 preapical posterodorsal setae. All setae and hairs of legs yellow.

Wing clear, with yellow veins. $\mathrm{R}_{1}$ bare apically on dorsal surface. Calypters and their margins yellowish. Halter yellowish.

Abdomen black, covered with yellow hairs. Male sternites 4 and 5 as in Fig. 3. Epandrium and surstyli as in Figs 4, 5.

COMPARISON. The new species is similar to Acerocnema breviseta (Zetterstedt, 1846), but has scutum with four shining stripes, also vibrissal angle well developed (Fig. 1). A. breviseta has scutum mostly shining, vibrissal angle not developed (Fig. 2).

ETYMOLOGY. The species is named in the honour of the Russian dipterist Dr. Kirill Borisovich Gorodkov, who made substantial contribution to the study of Scathophagidae.

DISTRIBUTION. Russia: Khabarosk Krai.

\section{Acerocnema nitens, sp.n.}

Figs. 6-9.

MATERIAL. Holotype $\sigma^{7}$, RUSSIA: Primorskyi Krai, SikhoteAlin Reserve, Cordon Yasnyi $\left(45.2359^{\circ} \mathrm{N} 136.5114^{\circ} \mathrm{E}\right), 18 . \mathrm{V} .2015$, M. Sergeev (ZMUM).

DESCRIPTION. Male (Fig. 6). Length of body 4.4 $\mathrm{mm}$. Length of wing $3.8 \mathrm{~mm}$.

Head in profile sligthly higher than wide. Frontal vitta yellow, matt; fronto-orbital plate black, shining. Face and parafacial black. Gena and postgena yellow. Ocellar triangle black, shining. Postcranium black in upper part and yellowish in lower third, delicately greyish dusted. Height of gena about 2 times less than vertical diameter of eye. Setae: 3 orbital, 4-5 frontal, 1 ocellar, 1 postocellar (small, parallel), 1 inner vertical, 1 outer vertical; $2-3$ pairs of strong vibrissae. Scapus, pedicel and postpedicel black. Postpedicel rounded api- cally, approximately 2 times as long as wide. Arista black, widened throughout its length, very short pubescent. Palpus slender, yellow.

Thorax black, shining, only meron, katatergite, anatergite and mediotergite delicately whitish dusted, meron with shining spot at middle. Acrostichals short, in irregular rows, not differentiated from other hairs on scutum, dorsocentrals $1+2$, intra-alars absent, supraalars 1+1, postpronotals 2, notopleurals 2, postalars 2 . Proepisternum with hairs in central part, with 2 long setae near lower margin. Proepimeron with 1 long seta. Anepisternum covered with hairs in posterior half and with 2 long setae along posterior margin. Katepisternum with hairs in ventral corner and 1 strong seta in posterodorsal corner. Anepimeron bare. Scutellum black, shining, with a pair of basal scutellar and a pair of apical scutellar setae. All thoracic setae and hairs yellow.

Legs yellow, only mid and hind coxae black. Mid tibia with 2 anterodorsal setae. Hind femur with 3-4 anterodorsal setae in apical third. Hind tibia with 2 anterodorsal and 1-2 posterodorsal setae, also with 1 preapical dorsal and 1 apical anteroventral setae.

Wing clear, with yellow veins. $\mathrm{R}_{1}$ setose on dorsal surface (Fig. 6). Calypters, margins of calypters yellowish. Halter yellowish.

Abdomen black, shining, covered with yellow hairs. Male sternites 4 and 5 as in Fig. 7. Epandrium and surstyli as in Figs 8, 9.

COMPARISON. The new species is similar to Acerocnema lobanovi Ozerov, 2006 by the structure of wing. Both species have $\mathrm{R}_{1}$ setose on dorsal surface. $A$. nitens, sp.n. is readily distinguished from $A$. lobanovi by fronto-orbital plate black, scutum and scutellum black shining, also by structure of male sternite 5 and genitalia. A. lobanovi has fronto-orbital plate yellow, scutum grey dusted, with two small shining spots behind transverse suture, scutellum is grey dusted.

DISTRIBUTION. Russia: Primorskyi Krai.

\section{Key to SPeCies of ACERocNema of Russia}

1. Vein $R_{1}$ setulose in apical part of dorsal surface (Fig. 6) ... 2

— Vein $\mathrm{R}_{1}$ bare ............................................................ 3

2. Fronto-orbital plate black. Scutum and scutellum black shining ................................................ A. nitens sp.n.

- Fronto-orbital plate yellow. Scutum grey dusted, with two small shining spots behind transverse suture; scutellum grey dusted ............................. A. lobanovi Ozerov

3. Postpedicel yellow, if darkened (female of A. arctica Ozerov) then fronto-orbital plate yellow completely or in anterior half ............................................................ 4

- Postpedicel black, fronto-orbital plate black completely

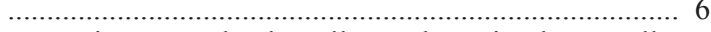

4. Postcranium completely yellow. Thoracic pleura yellow A. richterae Ozerov

Postcranium black in upper half and yellow in lower half. Thoracic pleura black

5. Scutellum grey dusted dorsally ........... A. Arctica Ozerov — Scutellum shining dorsally ............ A. barkalovi Ozerov 6. Scutum densely grey dusted ..................................... 7 


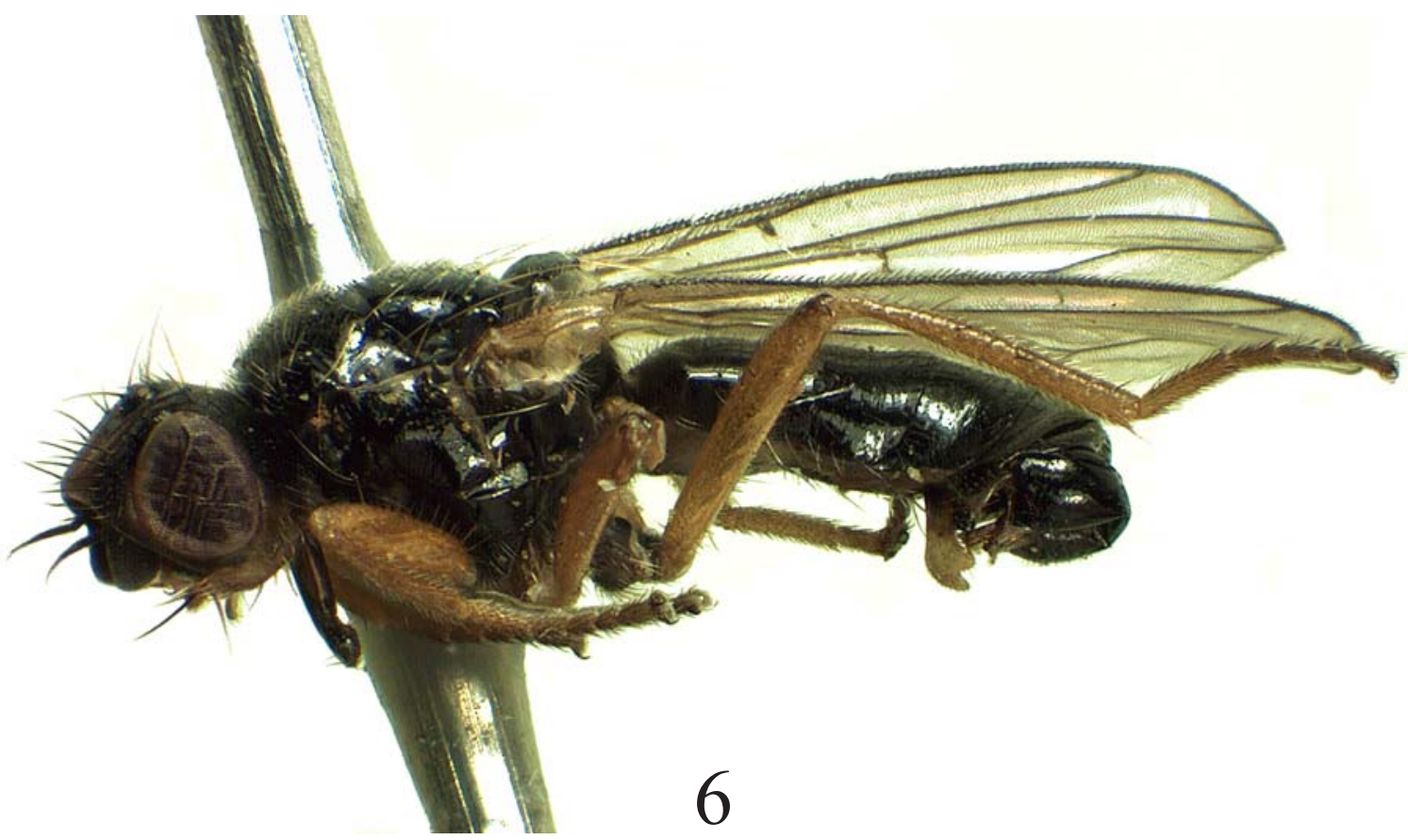

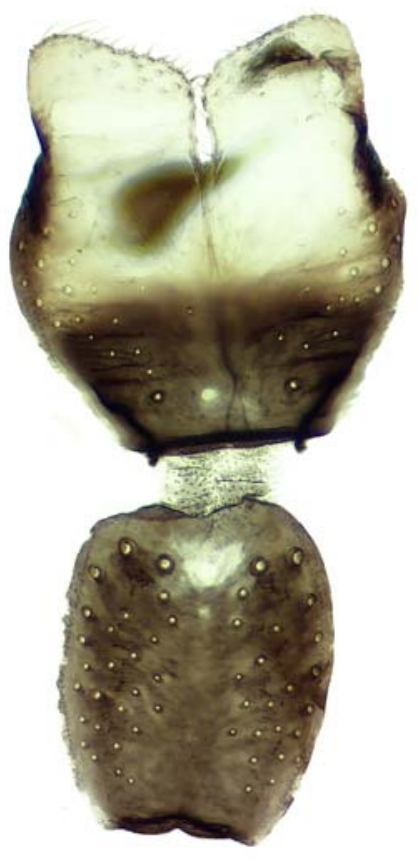

7

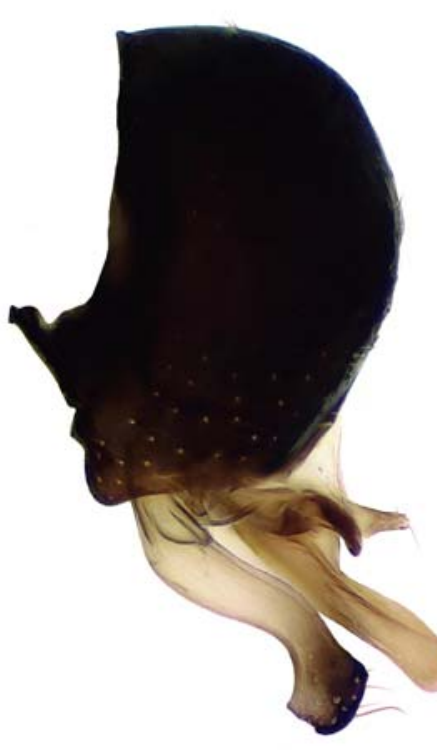

8

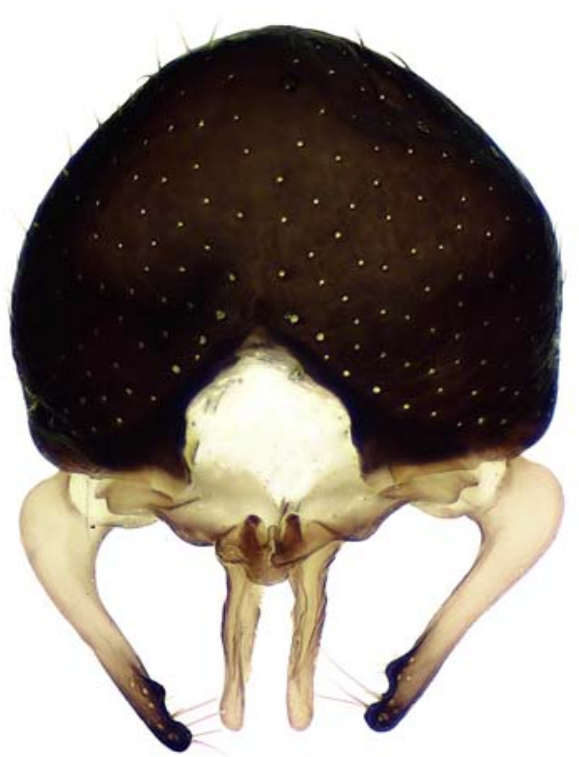

9

Figs. 6-9. Acerocnema nitens, sp.n., holotype $0^{7}: 6$ - imago before the abdomen is removed, lateral view; 7 - sternites 4 (lower) and 5 (upper); 8 - epandrium, cerci and surstyli, lateral view; 9 - same, dorsal view.

Рис. 6-9. Acerocnema nitens, sp.n., голотип О’: 6 - имаго до отчленения брюшка, сбоку; 7 - стерниты 4 (внизу) и 5 (вверху); 8 - эпандрий, церки и сурстили, сбоку; 9 - то же, сверху. 
- Scutum mostly shining or with four shining stripes ... 8

7. Palpus black. Scutellum shining dorsally A. macrocera (Meigen)

- Palpus yellow, sometimes with dark brown apex. Scutellum grey dusted dorsally

A. paradoxopyga Stackelberg

8. Scutum with four shining stripes, vibrissal angle well developed (Fig. 1) ............................. A. gorodkovi sp.n.

- Scutum mostly shining, vibrissal angle not developed (Fig. 2) A. breviseta (Zetterstedt)

ACKNOWLEDGEMENTS. The work was conducted within the research project of MSU Zoological Museum No. AAAA-A16-116021660077-3. Morphological studies and illustrations for this work were made on equipment purchased with the support of RFFI, research project No. 1604-01358 A.

We are very grateful to Dr. Olga Ovchinnikova (ZISP) and Mrs. Galina Suleymanova (ZISP) for the loan of the material of Acerocnema for study.

\section{References}

Cumming J.M., Wood D.M. 2009. Adult morphology and terminology // Brown B.V., Borkent A., Cumming J.M., Wood D.M., Woodley N.E., Zumbado M. (eds.). Manual of Central American Diptera. Vol.1. Ottawa: National Research Council Press. P.9-50.

Gorodkov K.B. 1986. Family Scathophagidae // Soós Á, Papp L. (eds.). Catalogue of Palaearctic Diptera. Vol. 11. Scatho-
phagidae-Hypodermatidae. Budapest: Akadémiai Kiadó. P.1141.

Iwasa M. 2014. Three new species of the genus Acerocnema Becker (Diptera: Scathophagidae) from Japan, with a key to the Palaearctic species // Studia Dipterologica. Vol.20 No.2. P.175-183.

McAlpine J.F. 1981. Morphology and terminology-adults // McAlpine J.F., Peterson B.V., Shewell G.E, Teskey H.J., Vokeroth J.R., Wood D.M. (Coordinators). Manual of Nearctic Diptera. Vol.2. Ottawa: Research Branch. Agriculture Canada. Monograph 27. P.9-63.

Ozerov A.L. 2006. [New species of the family Scathophagidae from Altai and Far East of Russia] // Euroasian Entomological Journal. Vol.5. No.4. P.333-336 [in Russian].

Ozerov A.L. 2013. Description of five new species and notes on taxonomy of Scathophagidae (Diptera) // Russian Entomological Journal. Vol.22. No.1. P.81-89.

OzerovA.L. 2014. Notes on types of three species of Scathophagidae (Diptera) described by I.W. Zetterstedt // Russian Entomological Journal. Vol.23. No.4. P.317-320.

Ozerov A.L. 2015. A new species of the genus Acerocnema Becker, 1894 (Diptera, Scathophagidae) from Buryatia, Russia // Caucasian Entomological Bulletin. Vol.11. No.1. P.211-213.

Stackelberg A.A. 1952. [New species of Cordyluridae (Diptera) from North of USSR] // Trudy Zoologicheskogo Instituta AN SSSR. Leningrad. Vol.12. P.405-407 [in Russian].

Vockeroth J.R. 1987. 103. Scathophagidae // McAlpine J.F. et al. (eds.). Manual of Nearctic Diptera. 2. Agriculture Canada, Research Branch, Ottawa, Monograph 28. P.1085-1097.

Stuckenberg B.R. 1999. Antennal evolution in the Brachycera (Diptera), with a reassessment of terminology relating to the flagellum // Studia Dipterologica. Vol.6. S.33-48. 